\title{
Investigation of EBA Digital Education Platform Used as the Medium of Distance Education in Turkey During COVID-19 Pandemic Process in Terms of Critical Thinking Skills
}

\author{
Dr. Pelin Kosece \\ Çukurova University, Turkey \\ Lutfi Uredi (Assoc., Prof., Dr.) \\ Mersin University, Turkey \\ Prof. Dr. Sait Akbasli (Prof. Dr.) \\ Hacettepe University, Turkey \\ Dr. Serkan Gokalp \\ Mersin University, Turkey
}

Doi:10.19044/ejes.v8no2a15

URL:http://dx.doi.org/10.19044/ejes.v8no2a15

\begin{abstract}
This paper focuses on investigating whether the contents of $6^{\text {th }}$ grade math lesson in the digital education platform (EBA) used in distance education in Turkey during the COVID-19 pandemic period are appropriate to the critical thinking standards. The contents of the math lesson, which are in the digital education platform (EBA) in 2020-2021 academic years, constitute the population of the study. The course contents, which belong to "Data Collection" and "Data Analysis" subtopics of $6^{\text {th }}$ grade math lesson used in Turkey's digital education platform (EBA) in 2020-2021 academic years, constitute the sample of the study. In the study, document analysis method is used. Based on the analysis conducted, it is concluded that the learning contents, which belong to "Data Collection and Evaluation" and "Data Analysis" subtopics of $6^{\text {th }}$ grade math lesson, are appropriate to clearness, accuracy, importance, sufficiency, depth, and precision standards of critical thinking. In accordance with the findings discovered, some suggestions are made on the process of distance education.
\end{abstract}

Keywords: Distance education and online learning, Elementary education, Mathematical learning, Critical thinking skills

\section{Introduction}

An event that happens anywhere in the world can have an influence all over the world or the failure occurring in one subsystem of the system can cause all of the subsystems to experience failure also. The pandemic, which is one of the events deeply influencing humanity, is defined by the Ministry of Health (2020) as "a disease or an infection occurring worldwide, or over a very large area, crossing the boundaries of countries, continents and usually affecting a large number of people". The COVID-19 pandemic, which started at the end of 2019 and has rapidly affected 
people all over the world, was declared as a pandemic by World Health Organization (WHO) in $11^{\text {th }}$ March 2020. COVID-19 pandemic still affected countries and systems adversely even at the end of 2020. The World Health Organization (WHO) defines health as "a state of complete physical, mental, and social well-being and not merely the absence of disease or infirmity". Health is the basic component for the continuance of human life in every aspect, and basic needs for human life are at the first stage of Maslow's hierarchy of needs (Maslow, 1943). Within this context, it is possible to say that COVID-19 pandemic is an obstacle to human health. The fact that the pandemic has influenced the whole world in socio-cultural, political, economic dimensions, and in a great deal of other dimensions in addition to its obvious results can possibly be seen in our lives (Bozkurt, 2020). The time left behind has shown that humans should be ready to change their normal lifestyle after the pandemic period and adapt to the new normal (Budak \& Korkmaz, 2020). Within this context, education is unquestionably one of the fields affected by COVID-19 pandemic. This situation forced educational institutions to carry out distance education and thus the process of using digital teachinglearning began (Bozkurt \& Sharma, 2020; Mulenga \& Marban, 2020). Formation of a new world order has been accompanied by a new educational paradigm. Perienen (2020) also stated that the educational sector has witnessed a paradigm shift. Due to the appearance of the first case of COVID19 in Turkey on $11^{\text {th }}$ March 2020, face-to-face education and training activities were suspended by the Ministry of National Education (MEB, 2020) on $16^{\text {th }}$ March 2020. In addition, distance education also started on $23^{\text {rd }}$ March 2020. Turkey showed great importance, which it attached to human health, by taking measures urgently as soon as the first case of the virus was recorded. Furthermore, all the ministerial units took measures and made decisions for the purpose of preventing the possible negative effects of the pandemic and enabling the country to develop. Within this context, the Ministry of National Education has enabled the education and training activities for the students to continue in the process of distance education by using TRT-EBA TV channels and EBA, which is the digital education platform of Turkey. Education Information Network, simply EBA, is an online social education platform provided to students free of charge by the General Directorate of Innovation and Educational Technologies, which is a unit of the Ministry of National Education (Tüysüz \& Çümen, 2016). EBA also began to provide services in Turkish educational system in 2012. The works which were carried out to enrich the platform in terms of contents and other aspects continued during the pandemic period. The digital learning contents such as videos, sounds, animations, enriched books, and educational games exist for all the grades in EBA. Additionally, academic support system, which was added to the platform in 2020, has provided the students preparing for university entrance exam with a medium which is run by artificial intelligence and machine learning technology (MEB, 2020). Furthermore, the live lessons, which are carried out via EBA, enable the teachers and students to meet online and interact with each other. This platform, which holds seminars for teachers to develop professionally, has become the $1^{\text {st }}$ educational website of the world and has been visited the most (MEB, 2020).

Just as the COVID-19 pandemic has influenced schools, teachers, and students, it has also influenced the researches in the field of education. Also, the researches, which have studied COVID19 and distance education in the context of different disciplines, were conducted abroad. According to Burke and Dempsey's (2020) research, it was reported that distance education had both advantages and disadvantages. Iwai (2020) stated that the educators who were ill-equipped in terms of internet and computer had difficulty and this situation caused them to hurry and feel anxious. In Turkey, the number of researches increases day by day. This involves the viewpoints of teachers and students in relation to distance education activities, which is carried out via distance 
education media. In the research conducted by Başaran et al. (2020), the students, the teachers, and the parents said that distance education had useful aspects. However, they had difficulties due to the fact that interaction was limited and the students could not participate in the lesson actively. This resulted to technical problems. In the study conducted by Karakuş et al. (2020), it was observed that the teacher candidates stated that skill based lessons could not be carried out by means of distance education. In the study, EBA platform was used as a medium of instruction, and it was concluded that the students who used Education Information Network (EBA) got better scores in the academic achievement tests than the ones who did not use it (Geçer, 2020). Nevertheless, the findings gained from the studies showed that face-to-face education was the first choice of the participants and EBA was useful in distance education activities.

Although face-to-face education and distance education differ in a great deal of dimensions, they are both used to improve important skills such as critical thinking skills. The concept of critical thinking skill has alot of definitions in the literature. For example, Nosich defined critical thinking as "objective and in-depth thinking without obsession" and referred to it as "the most developed and advanced way of thinking" (Aybek, 2015). According to Ennis (2004), the individual who has critical thinking skills, makes right decisions. In addition, the individuals who have critical thinking skill can motivate themselves and are more successful in school subjects (Karbalaei, 2012; Villavicencio, 2011). The people who are able to manage the process of thinking are the ones whose high level thinking skill is also developed (Aybek \& Yolcu, 2018). Ferret (1997) stated that critical thinking is a process which continues for a life time. Accordingly, the need to develop critical thinking skills is continuously growing. Therefore, critical thinking skill is an important thinking skill which should be focused on during the pandemic period, since the face-to-face education has been suspended. Thus, this study focuses on investigating EBA, which is used as a distance education platform during the pandemic period in Turkey and its contents in developing the students' critical thinking skills. This study further contributes to the literature in terms of the development of the students' critical thinking skills. Furthermore, it is possible to see alot of expressions related to critical thinking when the curricula, which were developed from the foundation of the Republic to 2020, are examined (Aydoğdu, 2020). This study also provides important insights into the studies on curriculum development that will be conducted in relation to distance education. Based on the research question "Are the EBA learning contents, which belong to "Data Collection and Evaluation" and "Data

Analysis" subtopics of $6^{\text {th }}$ grade math lesson, appropriate to the standards of critical thinking?" the answers to the sub-problems are sought below: Clearness, Accuracy, Importance, Sufficiency, Depth, and Precision.

\section{Method}

This study was designed according to qualitative research and document analysis method was used. Document analysis is the detailed analysis of the sources including written information about the target event or phenomena (Nergiz, 2014). "Qualitative researches have a variety and different patterns requires that the data collected at the end of the qualitative research should be analysed by means of creative, flexible, and various techniques." (Balc1, 2013, p.40). In this study, the data was analysed by means of descriptive analysis technique, which is used for analysing the data in qualitative research. "According to this technique, the data collected are summarized according to the themes, which are determined previously, and then they are interpreted" (Yildirım

\& Şimşek, 2013, p.156). The themes, which were determined in the study previously, are the standards of critical thinking, which Nosich (2012) introduced. The data of the study was collected by means of document analysis method. "The document analysis method involves the analysis of 
the written materials, including information about phenomenon or phenomena that are to be researched" (Yıldırım \& Şimşek, 2013, p.217). The documents analysed in this study are the learning contents, which belong to "Data Collection and Evaluation" and "Data Analysis" subtopics of $6^{\text {th }}$ grade math lesson, which are in Turkey's digital education platform, EBA.

\section{Study Group}

The population of the study is made up of learning contents from a $6^{\text {th }}$ grade math lesson on Turkey's interactive education site, EBA. The learning contents, which belong to "Data Collection and Evaluation" and "Data Analysis" subtopics of $6^{\text {th }}$ grade math lesson which are used in Turkey's digital education platform, EBA in 2020-2021 academic years constitute the sample of the study. These subtopics were analysed to determine whether they were appropriate to the standards of clearness, accuracy, importance, sufficiency, depth, breadth, and precision, which were Nosich's standards of critical thinking (2012).

\section{Process of Data Collection}

In this study, "Data Collection and Evaluation" and "Data Analysis" subtopics were chosen from the learning contents of EBA math lesson, which were used in $6^{\text {th }}$ grade of middle schools during the period of distance education in 2020-2021 academic years so that they could be analyzed. Purposeful sampling method was used in the study. Furthermore, these subtopics are interdisciplinary, and the acquirements and objectives that belong to these subtopics are found in every grade level in the middle school. Also, these subtopics are appropriate for having connection with real life, and the researchers who are domain experts on this field were the determining factors in selecting the subtopics of the unit for analysis. According to Yetim (2014), high-quality thinking should occur in authentic learning situations. It should also be open to improvement and should be transferable to other contexts and situations. Furthermore, critical thinking skill, which is an important high level thinking skill, is required for in-depth analysis and is a determining factor in the study of "Data Collection" and "Data Analysis" subtopics.

\section{Analysis of the Data}

The criteria were formed according to the critical thinking standards, which Nosich (2012) introduced for data analysis. The Checklist of Standards of Critical Thinking was made by preparing sub-questions for each criterion. Two domain experts were consulted for the validity of the criteria and for the Checklist of Standards of Critical Thinking. Thereafter, the criteria were reorganized into their final forms according to the feedbacks provided by the domain experts. The data acquired from EBA learning contents were thus analyzed according to these criteria. These analyses were performed according to the standards of clearness, accuracy, importance, sufficiency, depth, and precision, which are the critical thinking standards. The authors, who were domain experts, also performed analysis on the EBA learning contents independently of each other according to the criteria determined in order to ensure reliability.

\section{Findings}

The findings reveal whether the learning contents in EBA were appropriate to the standards of critical thinking. This was introduced by Nosich (2012) and explained with examples.

\section{Clearness}

Positive answers should be provided to the questions below for an expression to be appropriate to the standard of clearness: 
- Is the thought expressed clearly?

- Are there counterexamples disproving the expression?

- Is an eye-catching example presented? (Aybek, 2015)

It can be stated that the language used in digital course books, lectures, exercises, and multiple choice tests of EBA learning contents is appropriate to $6^{\text {th }}$ grade students' language level. The points to take into consideration while drawing a bar chart and the definitions of arithmetic mean and range are expressed clearly.

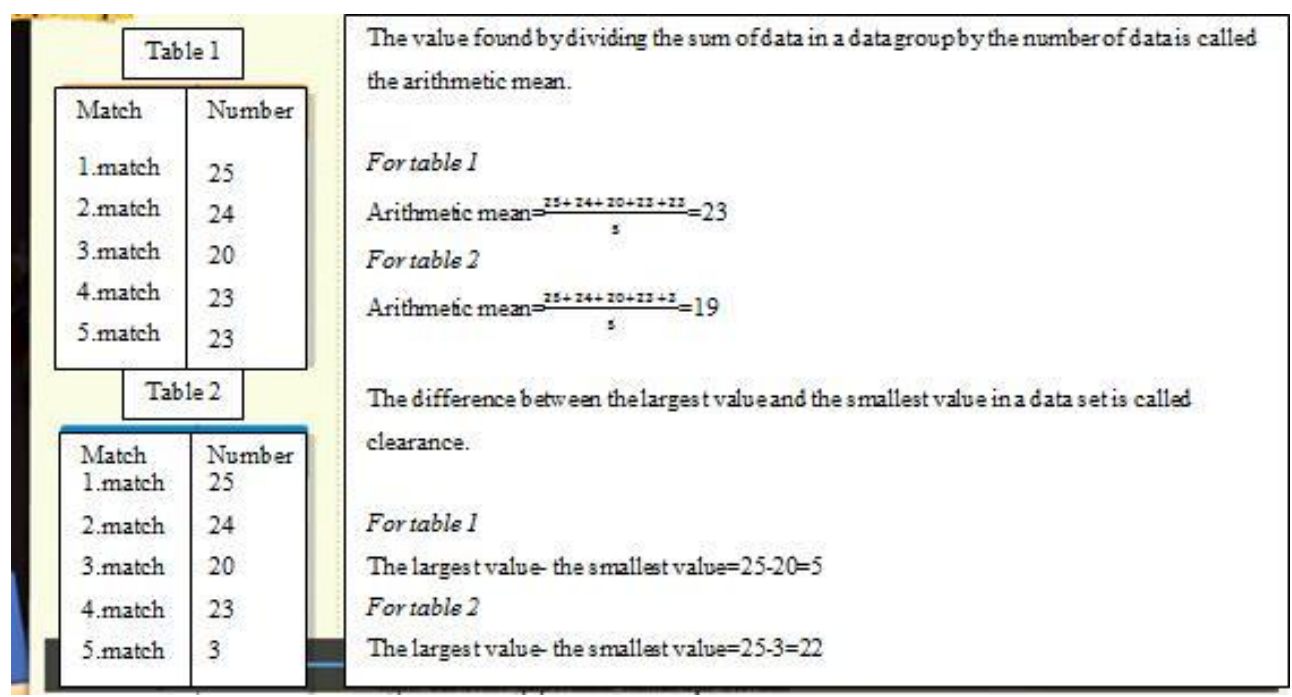

Figure 1. Example of sufficiently clear and understandable information

As shown in Figure 1, the information related to range is sufficiently clear and understandable in the video lecture related to "arithmetic mean and range" subtopic in EBA. Additionally, the definition of range, its examples, its aims, and its contributions to the study have been mentioned in the learning contents. However, the instructions of example activity in the interactive video lecture on the subject related to the comparison of two data sets were not sufficiently clear. More so, the data which needed to be used for the solution of the problem in the activity were not available in the video. In the chapters of 6 th grade "Data Collection and Evaluation" and "Data Analysis", appropriate examples related to the concepts were provided, while the counterexamples were not sufficiently used. As a result, it is possible to say that the chapters of "Data Collection and Evaluation" and "Data Analysis" that exist in the digital course book are mostly appropriate to the standard of clearness.

\section{Accuracy}

Positive answers should be provided to the questions below for an expression to be appropriate to the standard of accuracy:

- Is the reasoning accurate?

- Is the accuracy of the claims supported?

It is seen that the information that exists in digital course book, lecture on subject, exercises, and multiple choice tests of EBA learning contents is mostly accurate and the information provided are supported by examples. Additionally, the fact that the questions used as exercises in the learning contents are related to real life contributes to the accuracy of the information. 


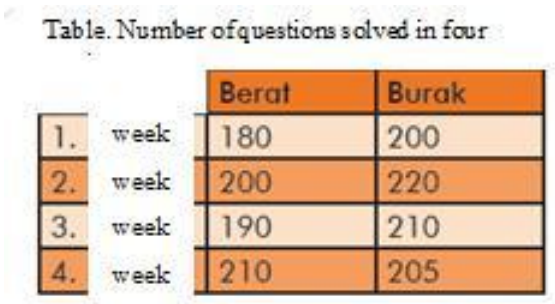

The number of questions Berat and Buraksolved for 1 month is given in the table above. Whichone is less clear in the number of questions it solves according to this table?

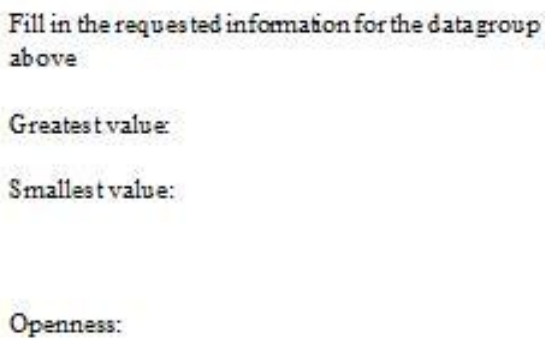

Figure 2. The expression whose accuracy is not supported sufficiently

The effect of the range being small or large due to the differences between the data is mentioned in the expression on page 147 of digital course book. However, based on question 9, using the values in which the differences between data sets is more explicit can be very useful in terms of making the expression concrete and supporting its accuracy. When the information, which belongs to the subtopics of "Data Collection and Evaluation" and "Data Analysis" existing in digital course book, lecture on subject, exercises, and multiple choice tests of EBA learning contents is analyzed in terms of the standard of accuracy, it can be stated that this information is appropriate to this standard.

\section{Importance}

Positive answers should be provided to the questions below for an expression to be appropriate to the standard of importance:

- Is the most important thing focused on in the reasoning used?

- Can the reasoning used be summarized? (Aybek, 2015)

According to $6^{\text {th }}$ grade math teaching curriculum (MEB, 2018), the ability to do research, produce information, and use the information which is produced is one of the special objectives of math teaching curriculum. When EBA learning contents, which belong to the subtopics of "Data Collection and Evaluation" and "Data Analysis" were analysed, it was shown that the examples in these contents could be used in different disciplines or in daily life with similarities based on the examples in the learning contents. This is because the graphics are one of the subjects which can be seen in different disciplines such as daily life, advertisements, banks, news, and science and technology. 


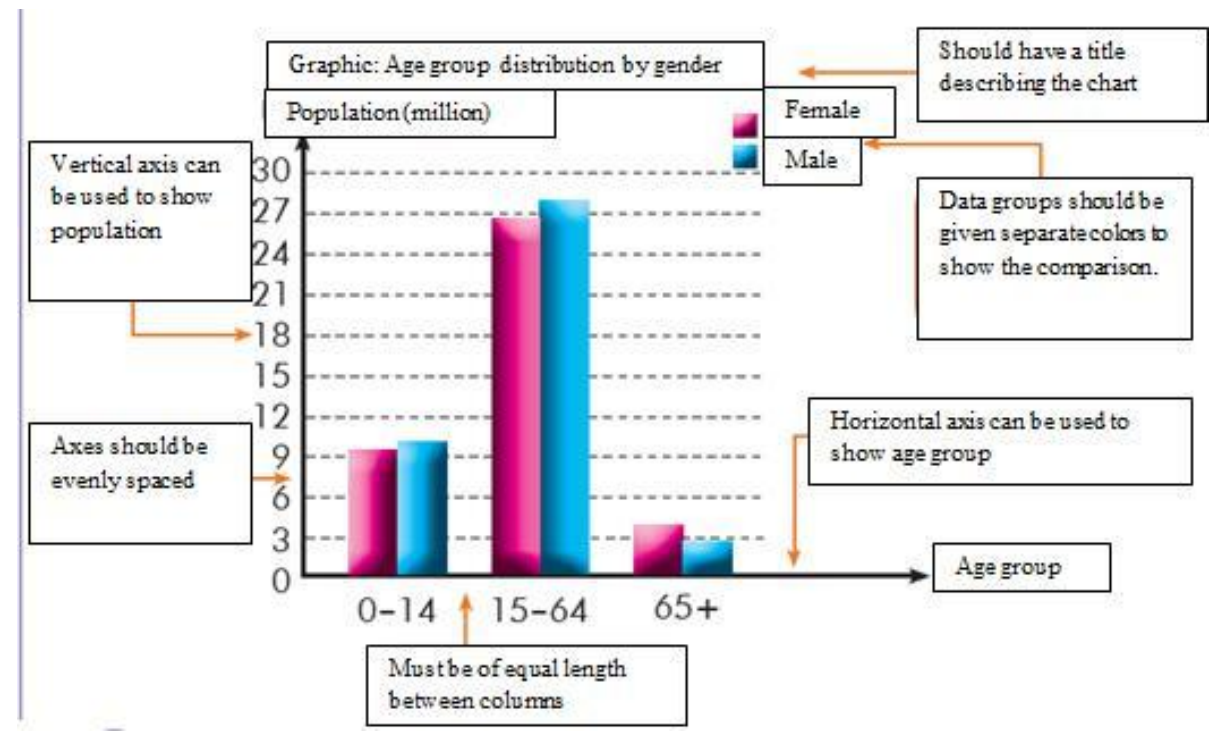

Figure 3. The example of providing important information conspicuously

Based on these examples, it can be stated that the information which belongs to the subtopics of "Data Collection and Evaluation" and "Data Analysis" existing in digital course book, lecture on subject, exercises, and multiple choice tests of EBA learning content is appropriate to the standard of importance.

\section{Sufficiency}

Positive answers should be provided to the questions below for an expression to be appropriate to the standard of sufficiency:

- Are the expressions considered sufficiently?

- Are there any other necessary points to pay attention to?

It was shown that the information was sufficient for the achievement of the objectives.

Also, the number of examples and activities related to the subject that exists in EBA learning contents are sufficient. The multiple choice tests and skill based tests, which are components of EBA learning contents, enable the things that are learned to be reinforced and are appropriate to the standard of sufficiency. Furthermore, the fact that the questions that exist in these tests have the quality of providing connection with real life helps the results to be achieved by making the learners think about the expressions sufficiently. 
Average fuel consumption of a vehicle refers to the amount of fuel consumed by 100 kilometers.

Before starting a journey of $400 \mathrm{~km}$, Serd ar reset the indicator showing the average fuel

consumption of her vehicleas in Figure 1.
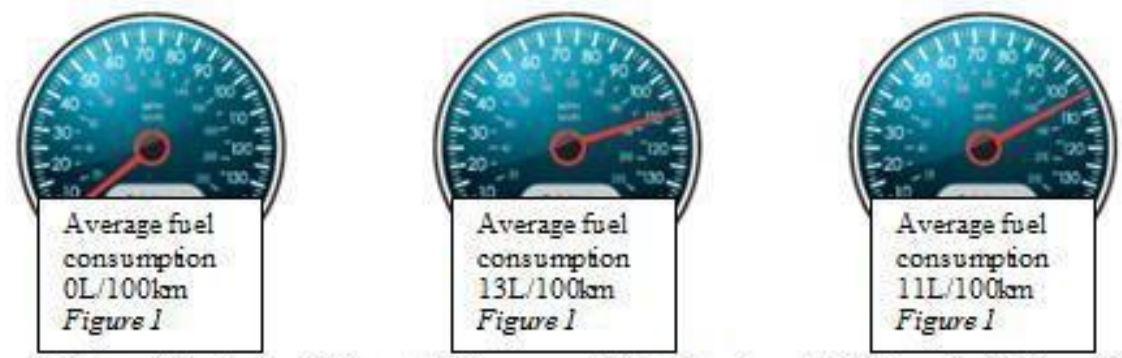

After traveling the first $100 \mathrm{~km}$ of this joumey, while Serdar showed the information in Figure 2 , he reset it again and continved on the road. When Serd ar completed this joumey, the indicator of her vehicle showed the information in Figure 3.

\section{$11,2 \mathrm{~L} / 100 \mathrm{~km}$ (B) $11,5 \mathrm{~L} / 100 \mathrm{~km}$ (C) $11,8 \mathrm{~L} / 100 \mathrm{~km}$ (D) $12 \mathrm{~L} / 100 \mathrm{~km}$}

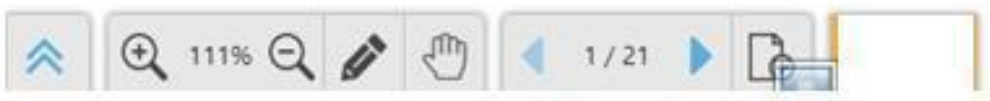

Figure 4. Sample question that exists in skill based tests

As shown in Figure 4, it is possible to reinforce the things learned and also reflect on the expressions and concepts when there are questions that are aimed at achieving the results by providing connection with real life. It is also possible to say that the use of EBA learning contents by means of interactive whiteboard is efficient in enabling the students to focus on the questions. As a result, the subtopics of "Data Collection and Evaluation" and "Data Analysis" existing in EBA learning content is appropriate to the standard of sufficiency.

\section{Depth}

Positive answers should be provided to the questions below for an expression to be appropriate to the standard of depth:

- Is there an in-depth look under the surface based on the reasoning used?

- Are other related perspectives taken into account?

It can be concluded that the examples, which have been made while EBA lesson contents have been prepared, are considered sufficient. Owing to the nature of math lesson, the results of four operations are true or false. Nonetheless, they are performed in different paths. When considered from this perspective, it was shown that the results of numerical operations in the examples that existed in EBA learning contents were correct. More so, the data used in the examples were built on solid bases. For instance, the example that exists in the chapter of "Let's learn together" on page 149 of digital course book analyses the distribution of age groups according to gender in Turkey in 2016. The data used in this example was acquired from the records of Turkish Statistical Institute (TUIK). In the example, which was extracted from the video lecture on the subject related to data organisation, the same data was shown in the form of vertical and horizontal column charts and the charts were formed by means of two different perspectives. 
According to Figure 5, the presentation of the data by means of both horizontal and vertical column charts was made in order to enable the learners to look at the subject from different perspectives. The horizontal or vertical form of the column chart does not influence the result in any way.

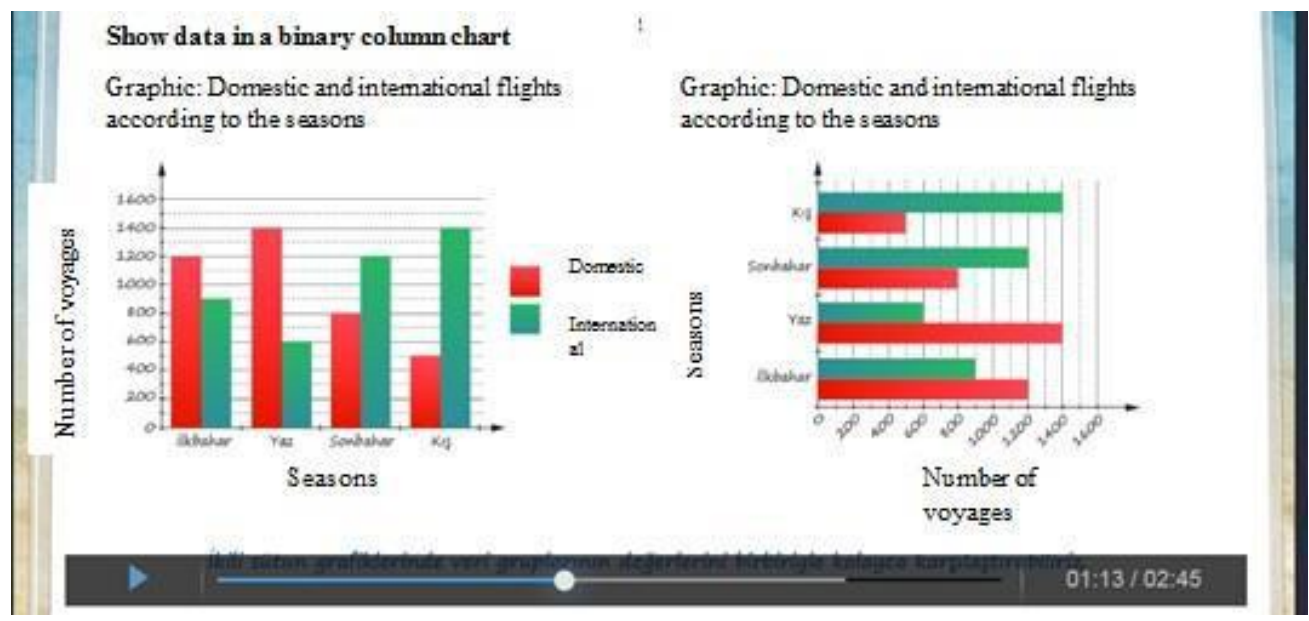

Figure 5. Forming column charts with different perspectives

According to these analysis, the subtopics of "Data Collection and Evaluation" and "Data Analysis" existing in EBA learning content is appropriate to the standard of depth.

\section{Precision}

Positive answers should be provided to the questions below for an expression to be appropriate to the standard of precision:

- Is the reasoning used precise enough?

- Is the precision provided with a degree that the target group needs?

It was shown that they were appropriate to the standard in terms of the precision of results. Thus, the results of the examples and questions that exist in EBA learning contents can be obtained.

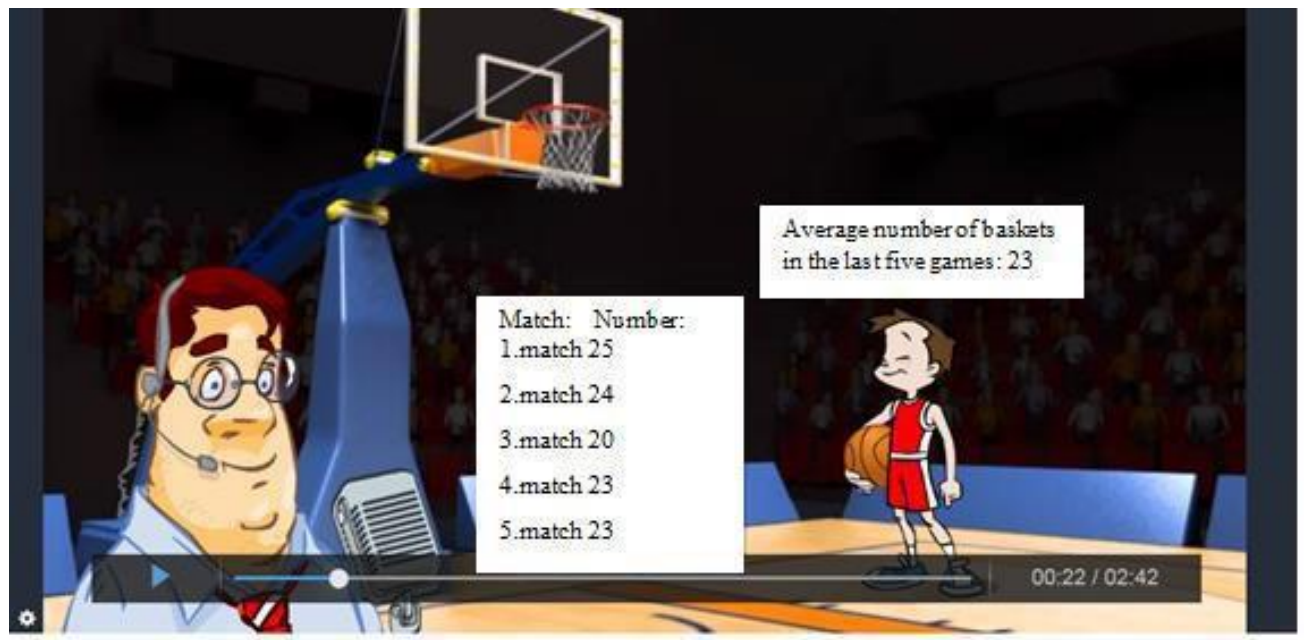

Figure 6. An example of a video lecture that is appropriate to the target group for using reasoning In the video lecture, as shown in Figure 6, the concepts of arithmetic mean and range were

focused on. Through this video, which is appropriately prepared for the age and level of $6^{\text {th }}$ grade students, who are target groups, it is possible to enable students to use reasoning related to the 
subject. In addition, more detailed explanations and examples related to the use of arithmetic mean or range for comparing data sets and describing the situation can be provided. While two sets of data are compared in terms of success, it is more useful to determine arithmetic means first. If the arithmetic means of two groups are equal, it is important to look at the range in order to determine the more successful group. Consequently, the information of the range is efficient in determining the order of data, which is supported by examples. This contributes to making the subject information more detailed. Accordingly, it can be stated that the expressions has precision as much as $6^{\text {th }}$ grade students, who are the target group. Also, real life needs, different disciplines, and the detailed information with the support of examples contributes to its appropriateness based on the standard of precision.

\section{Conclusion}

The COVID-19 pandemic has resulted in a socio-economic influence in many fields including the education sector. UNESCO predicts that approximately 900 million students were influenced by this after face-to-face education in schools ended in more than 100 countries because of the pandemic (Nicola et al., 2020). The children miss the opportunity to have academic and socioemotional learning, formative relationships with peers and adults, playing games with schoolmates, and satisfying their other needs while they are at home (Levinson, Çevik \& Lipsitch, 2020). In the study done by Livari, Sharma, and Olkkonen (2020), the digital transformation of daily life during the pandemic period was researched and it was observed that all children were not equal in terms of their participation in digital education. This created problems related to the abilities and skills needed to use digital media for teaching-learning activities. However, according to Code, Ralph, and Forde (2020), the pandemic created important opportunities for education and caused the blended learning activities to result in transformation. As a result, blended learning activities started including more personal and individualized education. Distance education involves the process whereby the learners are distant from each other, and the learning sources and the interaction is carried out by means of telecommunication systems (Simoson, 2006). The activities of distance education are carried out in Turkey and all over the world due to the COVID-19 pandemic (Kaynar et al., 2020). The Ministry of National Education has created a distance educational environment which support the students academically and socially (Özer, 2020). The students can also continue their learning activities without the limitation of time and place by means of EBA. Turkey has been able to effectively do this within the distance education period (Özbey \& Koparan, 2020). When EBA learning contents, which belonged to "Data Collection and Evaluation" and "Data Analysis" subtopics of elementary school $6^{\text {th }}$ grade math lesson, were evaluated in terms of the standards of critical thinking, it was observed that they were appropriate to clearness, accuracy, importance, sufficiency, depth, and precision standards of critical thinking. In the study done by Erümit (2020), it was concluded that EBA TV supported the students in learning and provided them with psychological support. Furthermore, the concepts explained were visualized sufficiently and counterexamples were not sufficiently used in terms of the standard of clearness. Errors were not determined in the examples including four operations in the analysis conducted in terms of the standard of accuracy. In addition, the subjects in the course contents are presented in the context of real life situations, and this feature of subjects presented in connection with real life situation is efficient in ensuring the accuracy of the information. It is also possible to say that the applications that exist in EBA system increase studentteacher interaction by creating learning situations which are quite similar to real environment. Özer and Suna (2020) stated that the applications of live lesson existing in EBA enabled the teachers to have live interaction with 
their students. Within this context, it is expected that the applications of live lessons support students in acquiring the target skills by creating learning environments which are similar to real classroom environment.

Thus, the chapters of "Data Collection and Evaluation" and "Data Analysis" were appropriate to the standard of importance. The examples that exist in the unit are related to real life, and it emphasizes the importance of the subject in a way that is appropriate to the level of $6^{\text {th }}$ grade. Also, the chapters analysed were generally appropriate to the standard of sufficiency. The examples and exercises in the chapters are sufficient, but the use of performance homework will be efficient in reinforcing the things that are learned. Using different perspectives related to the subject in the learning contents during the process of providing information is efficient in providing the standard of depth. The chapters of "Data Collection and Evaluation" and "Data Analysis" are also appropriate to the standard of precision. Hence, they are appropriate to Nosich's (2012) standards of critical thinking. In the literature review to analyse the printed course books at different grade level, which had been used for years in Turkey, it was observed that there were also studies in which the criteria used in their analysis overlapped the standards of critical thinking (Ünsal \& Güneş, 2002; Ünsal \& Güneş 2004; Atıc1 et al., 2007; Demirbaş, 2008; Gülersoy, 2013). Ünsal and Güneş (2004) analysed the course book with a critical perspective in terms of scientific content, educational design, book layout, lack of information, language, and expression and concluded that the course book was generally appropriate to the criteria determined. Atıc1 et al. (2007) conducted a critical analysis of biology subjects of middle school course books and used teachers' points of view as data. It was concluded that the books were appropriate to the students' level in terms of orienting the students towards research, enabling them to participate in the lesson, and using comprehensible language and sentence structure. Therefore, it can be stated that the similar findings of the researches, which were done previously, support the findings of this research.

Thus, when the literature was analysed, it was shown that the analysis of the course books used in different years and in different grade levels in Turkey were performed with a critical point of view. In this study, EBA, i.e., digital education platform, which was used for distance learning activities in Turkey and due to the COVID-19 pandemic was analysed within the frame of critical thinking standards. According to the findings, it was concluded that EBA lesson contents in which course books also existed were at the level of contributing to the development of the students' critical thinking skills. Therefore, in accordance with these findings, it is suggested that:

- In the case where COVID-19 pandemic continues and during the process of distance learning, the studies in relation to the development of students' higher level thinking skills can be made within the context of different disciplines.

- The training and seminars for students and parents can be provided to enable them to benefit from thinking skills when they have psycho-social troubles during the pandemic period. 


\section{References}

Atıcı, Y., Samancı, N.K., \& Özel, Ç.A. (2007). The critical analysis of elementary school science course books in terms of the subjects of biology and teachers' points of view, Journal of Turkish Educational Sciences, 5(1), 115-133.

Aybek, B. (2015). Guide to interdisciplinary critical thinking. Ankara: Anı Publishing Company. Aybek, B. \& Yolcu, E. (2018). Primary and middle school teachers' awareness of critical thinking, Journal of Higher Education \& Science, 8(3), 567-573.

Aydoğdu, İ. (2020). Investigation of the relationship between primary school $4^{\text {th }}$ grade students' perceptions of critical thinking and their academic success (Master's Thesis, Erzincan Binali Y1ldırım University Social Sciences Institute).

Balc1, A. (2013). Research, method, technique and principles in social sciences $10^{\text {th }}$ edition, Ankara: Pegem .

Başaran, M., Doğan, E., Karaoğlu, E., \& Şahin, E. (2020). A study on the efficiency of distance education caused by coronavirus (Covid-19) pandemic. Journal of Academia Educational Research, 5(2), 179-209.

Bozkurt, A. (2020). Evaluations of education during the coronavirus (Covid-19) pandemic process and after the pandemic: new normal and new education paradigm. Journal of Open University Practises and Researches, 6(3), 112-142.

Bozkurt, A. \& Sharma, R. C. (2020). Emergency remote teaching in a time of global crisis due to coronavirus pandemic. Asian Journal Of Distance Education, 15(1), İ-Vi. Https://Doi.Org/10.5281/Zenodo.3778083.

Budak, F. \& Korkmaz, Ş. (2020). A general evaluation of Covid-19 pamdemic process: Turkey Sample. Journal of Social Research and Management, (1), 62-79.

Burke, J. \& Dempsey, M. (2020). Covid-19 Practice in primary schools in Ireland report. National University Of Ireland Maynooth, Ireland. Https://Www.İnto.İe/App/Uploads/2020/04/Cov1d-19-Practice-İn-Primary-Schools-Report1.Pdf.

Code, J., Ralph, R., \& Forde, K. (2020). Pandemic designs for the future: perspectives of technology education teachers during COVID-19. Information and Learning Sciences, 5(6), 419431.

Demirbaş, M. (2008). Analysis of $6^{\text {th }}$ grade science and technology course books in terms of specific variables. Journal of Dicle University Ziya Gokalp Education Faculty, (11), 53-68.

Ennis, H.R. (2004). Applying soundness standards to qualified reasoning. Informal Logic, 24(1), 2004, 23-39.

Ferrett, S. (1997). Peak performance: success in college and beyond. New York: Glencoe Mcgraw-Hill.

Erümit, S.F. (2021). The distance education process in $\mathrm{K}-12$ schools during the pandemic period: evaluation of implementations in Turkey from the student perspective. Technology, Pedagogy and Education, 1-20. DOI: 10.1080/1475939X.2020.1856178

Nergiz, H.G. (2014). Bibliometric profile of graduate theses on tourism (1990-2013). VII. Research congress of graduate tourism students, 04-05 April 2014, Kuşadas1, Aydın, 212-221. Gülersoy, A. E. (2012). Analysis of social sciences course book in terms of some features in the search of ideal course book. International Journal of New Trends in Arts, Sports \& Science Education (Ijtase), 2(1), 8-26.

Geçer, A.K. (2020). The effect of using Education Information Network (EBA) in science lessons on the middle school students' achievement tests related to solar system and eclipse. Journal of Siirt University Social Sciences Institute, 8(15), 117-129. 
Iwai, Y. (2020). Online learning during the covid-19 pandemic: What do we gain and what do we lose when classrooms go virtual?. Scientific American.

Https://Blogs.Scientificamerican.Com/Observations/Online-Learning-During-The-Covid-19Pandemic/.

Iivari, N., Sharma, S., \& Ventä-Olkkonen, L. (2020). Digital transformation of everyday lifeHow COVID-19 pandemic transformed the basic education of the young generation and why information management research should care?. International Journal of Information Management, 55, 102183.

Karbalae, A. (2012). Critical Thinking and academic achievement. Íkala, Revista De Lenguaje Y Cultura, 17(2), 2012, 121-128.

Kaynar, H., Kurnaz, A., Doğrukök, B., \& Barışık, C. Ş. (2020). The middle school students' points of view about distance education. Electronic Turkish Studies, 15(7), 3269-3292.

Levinson, M., Çevik, M., \& Lipsitch, M. (2020). The reopening of primary schools during the pandemic. The New England Journal of Medicine, 383, 981-985.

Maslow, A. H. (1943), A Theory of human motivation. Psychological Review, 50(4): 370-396.

Ministry of National Education (MEB) (2020). Distance Education, retrieved on 20.12.2020.

Http://Covid19.Meb.Gov.Tr/Covid19.Html?Cat=Rapor.

Mulenga, E. M. \& Marbán, J. M. (2020). Is Covıd-19 The gateway for digital learning in mathematics education. Contemporary Educational Technology, 12(2), Ep269. Https://Doi.Org/10.30935/Cedtech/7949.

Nicola, M., Alsafi, Z., Sohrabi, C., Kerwan, A., Al-Jabir, A., Iosifidis, C., \& Agha, R. (2020). The socio-economic implications of the coronavirus pandemic (COVID-19): A review. International Journal of Surgery, 78, 185.

Nosich, G. M. (2012). Learning to think things through: A guide to critical thinking across the curriculum, Centers for teaching and technology-book library.

Özbey, A. \& Koparan, T. (2020). Effect of teaching equation aided by Education Information Network (EBA) on middle school students' success, attitude and motivation. Journal Of Computer And Education Research, 8(16), 453-475.

Özer, M. (2020). Educational policy actions by the Ministry of National Education in the times of COVID-19 pandemic in Turkey. Kastamonu Eğitim Dergisi, 28(3), 1124-1129.

Özer, M. \& Suna, H. E. (2020). COVID-19 pandemic and education. Reflections on the pandemic in the future of the worlds, 157-178.

Perienen, A. (2020). Frame works for ICT integration in mathematics education- a teacher's perspective. Eurasia Journal of Mathematics, Science and Technology Education, 16(6), Em1845. Https://Doi.Org/10.29333/Ejmste/7803.

Simonson, M. (2006). Teaching Courses Online: A Challenge For The Field. Fischler College Of Education: Faculty Articles. 144. Https://Nsuworks.Nova.Edu/Fse_Facarticles/144.

T.R. Ministry of health (2020). Covid-19 dictionary. retrieved on 20.12.2020. Https://Covid19.Saglik.Gov.Tr/Tr-66493/P.Html.

Tüysüz, C. \& Çümen, V. (2016). Middle school students' viewpoints on EBA course web site. Uşak Üniversitesi Sosyal Bilimler Dergisi, 9(27/3), 278-296.

Ünsal, Y. \& Güneş, B. (2002). A critical outlook on MEB primary school $4^{\text {th }}$ grade science course book in terms of physics subjects as an example of book review study. Gazi University Journal of Gazi Educational Faculty, 22(3), 107-120.

Ünsal, Y. \& Güneş, B. (2004). A critical analysis of MEB high school $1^{\text {st }}$ grade physics course book as an example of book review study. The Journal of Turkish Educational Sciences, 2(3), 305-321 
Villavicencio, F. T. (2011). Critical thinking, negative academic emotions, and achievement: a mediational analysis. The Asia-Pacific Education Researcher, 20(1), 2011, 118-126.

WHO (1946). The International Health Conference. New York: 19 June-22 July.

Yetim, N. (2014). The relationship between reflective thinking skills, academic stress among students at secondary education level and their success in foreign language lesson (Master's thesis). Gaziosmanpaşa University Institute of Science, Tokat.

Yıldırım, A. \& Şimşek, H. (2013). Qualitative research methods in social sciences, $9^{\text {th }}$ edition. Ankara: Seçkin Publishing Company. 